\title{
Gastric residual volume factors after bowel preparation with mannitol express
}

\author{
Hélcio Pedrosa BRIT0 ${ }^{1}$, Beatriz SUGAI', Filipe Tomishige CHAVES² ${ }^{2}$ Edson IDE \\ Rodrigo A RODRIGUES ${ }^{1}$ and Dalton Marques CHAVES ${ }^{1}$
}

\begin{abstract}
Background - Bowel preparation with mannitol is a well-established method in Brazil. However, factors that interfere with the gastric emptying time period are yet to be known. Knowing these factors may favor the examination scheduling logistics and the individualized orientation for each patient. Objective - Know the factors that can contribute to the gastric emptying time after intestinal preparation with express mannitol. Methods - This is a prospective observational study to know factors that may contribute on the gastric emptying timing: predominant type of diet, comorbidities, medication usage, previous surgeries, number of evacuation per week, bearer of bowel obstipation, fecal type, diet type, number of evacuations after the home usage of bisacodyl before the ingestion of mannitol and number of evacuations after the ingestion of mannitol until reaching a proper bowel preparation. Before starting the colonoscopy exam, an upper digestive endoscopy exam was made to aspirate the gastric content. Results - Sample was composed of 103 patients, 55 (53.4\%) women, medium age $61( \pm 12.1)$ years, medium weight $75.3( \pm 14.1) \mathrm{kg}$, medium height 1.7 $( \pm 10) \mathrm{m}$ and medium BMI of $26.6( \pm 3.9) \mathrm{kg} / \mathrm{m}^{2}$. Average gastric residual volume was $120.9(0-900) \mathrm{mL}$. Gastric residual volume (GRV) below 100 $\mathrm{mL}\left(\mathrm{GRV} \leq 100 \mathrm{~mL}\right.$ ) occurred in $45(43.6 \%)$ patients, $24(53.3 \%)$ women, medium age of 61.0 years and medium BMI of $26.7 \mathrm{~kg} / \mathrm{m}^{2} . \mathrm{Gastric}$ residual volume above $100 \mathrm{~mL}$ (GRV >100 mL) occurred on $58(56.3 \%)$ patients, $29(50 \%)$ women, medium age of 61.0 years and medium BMI of $26.2 \mathrm{~kg} /$ $\mathrm{m}^{2}$. Comparing both groups, average fasting time period after the ingestion of mannitol was significantly higher on the group with GRV $\leq 100 \mathrm{~mL}$ than group with GRV >100 mL, 123.1 (60-246) vs 95.3 (55-195) minutes, respectively. There was also statistical significance concerning the usage of ezetimibe $6(13.7 \%)$ in the group with GRV $\leq 100 \mathrm{~mL}$ and statistical significance in the group with GRV $>100 \mathrm{~mL}$ concerning the usage of paroxetine $3(6.7 \%)$ and tadalafil $3(6.7 \%)$ and surgical history of prostatectomy $3(6.7 \%)$ and bridle withdrawal $3(6.7 \%)$. Conclusion - We may conclude in this study that the usage of ezetimibe and fasting above 2 hours after the ingestion of mannitol decrease significantly the incidence of a GRV $>100 \mathrm{~mL}$. The usage of paroxetine, tadalafil and surgical history of prostatectomy or bridle withdrawal may contribute to increase de incidence of a GRV $>100 \mathrm{~mL}$. Keywords - Mannitol; sedation; respiratory aspiration of gastric contents; sedation, moderate; moderate sedation; sedation, conscious.
\end{abstract}

\section{INTRODUCTION}

Colonoscopy is a well-established method for diagnostic and therapeutic examination. For its execution, it is of great importance to properly prepare the colon.

Ingestion of mannitol within 2 hours (known as "mannitol express") is the most common way of bowel preparation in Brazil. One of the disadvantages of this method is the large volume of solution that patients must ingest in a short period of time, predisposing to aspiration during colonoscopy in case of considerable amount of liquid present in the gastric chamber.

To perform the colonoscopy it is recommended a 2-hour minimum fasting after the ingestion of liquids ${ }^{(1)}$, and there is no knowledge of any factors that may contribute or hinder the gastric emptying of mannitol nor there is any study about the subject.

Knowing the factors that may affect the gastric emptying time period favors the examination scheduling logistics and the individualized orientation for each patient.

\section{METHODS}

This is a prospective observational study performed at the Endoscopy Service of Fleury Medicina e Saúde between May 2017 and May 2018, after approval by the institution's Ethics Committee. Indications for colonoscopy were screening or surveillance for colorectal cancer.

Eligible patients were: patients who had agreed to participate the research; age $>18$ years-old; $\mathrm{BMI}<40 \mathrm{~kg} / \mathrm{m}^{2}$; ASA 1 and ASA2 and be accompanied by someone of age $\geq 18$ years-old.

Patients received the same instructions for bowel preparation: no ingestion of food containing any sort of seeds 5 days prior to the exam; one day before the exam, have a fiber-free diet and take two pills of bisacodyl at $05: 00 \mathrm{pm}$ and $10: 00 \mathrm{pm}$. At the day of the examination, 4 hours before the colonoscopy, they were asked to ingest $500 \mathrm{~mL}$ of mannitol diluted with $500 \mathrm{~mL}$ of water.

Bowel cleaning was confirmed by nursery staff by the presentation of watery and light-colored evacuation. Number of evacuations to clean the colon and times of the first, third and last evacuation were all duly noted.

Declared conflict of interest of all authors: none

Disclosure of funding: no funding received

${ }^{1}$ Fleury Medicina e Saúde, Departamento de Endoscopia, São Paulo, SP, Brasil. ${ }^{2}$ Faculdade de Medicina de Santo Amaro, Santo Amaro, SP, Brasil.

Corresponding author: Hélcio Pedrosa Brito. E-mail: helcio.brito@grupofleury.com.br 
Before bowel preparation in the institution, patients signed a Free and Informed Consent Form, answered clinical questionnaire and received orientations about the research. Questioned data were: predominant type of diet, comorbidities, medication usage, previous surgeries, number of evacuation per week, bearer of bowel obstipation, fecal type, diet type, number of evacuations after the home usage of bisacodyl before the ingestion of mannitol.

Patients were asked which type of diet they believed to fit in: protein, carbohydrate or vegetables (fibers) predominant diet.

Intestinal obstipation definition was based on the Rome IV Criteria $^{(2)}$ and fecal classification was made according to the Bristol Stool Chart ${ }^{(2)}$.

Upon the confirmation of intestinal cleaning and the await of a 1-hour minimum fasting after the ingestion of mannitol, upper digestive endoscopy was performed for aspiration and volume assessment of the gastric content, followed by colonoscopy. Patients were sedated with midazolam $(5 \mathrm{mg})$, fentanyl $(50 \mu \mathrm{g})$ and a progressive dose of propofol, until reaching an appropriate level of sedation.

According to the findings in the literature about the subject, gastric residual volume (GRV) of $100 \mathrm{~mL}^{(3-8)}$ was determined as the ideal reference value to minimize the risk of bronchial aspiration.

A designated endoscopist made the data gathering and another expert endoscopist performed the colonoscopy exams.

Data were evaluated by means of the Kolmogorov-Smirnov test and answers were converted to binary variables, with residual volumes up until $100 \mathrm{~mL}$ and volumes above $100 \mathrm{~mL}$. Mann-Whitney U Test and chi-square distribution were applied with the purpose of verifying the existence of linear relation between the metric variables. A significance level of 5\% was considered for the results interpretation. SPSS 22.0 software was used to perform the analyses.

\section{RESULTS}

Sample was composed of 103 patients, 55 (53.4\%) women, medium age $61( \pm 12.1)$ years, medium weight $75.3( \pm 14.1) \mathrm{kg}$, medium height $1.7( \pm 10) \mathrm{m}$ and medium BMI of $26.6( \pm 3.9) \mathrm{kg} /$ $\mathrm{m}^{2}$. Average gastric residual volume was $120.9(0-900) \mathrm{mL}$.

Gastric residual volume below $100 \mathrm{~mL}(\mathrm{GRV} \leq 100 \mathrm{~mL})$ was found in $45(43.6 \%)$ patients and above $100 \mathrm{~mL}(\mathrm{GRV}>100 \mathrm{~mL})$ in $58(56.3 \%)$. Demographic data are demonstrated in TABLE 1.

TABLE 1. Demographic data of the patients.

\begin{tabular}{lccc}
\hline $\begin{array}{c}\text { Total number of } \\
\text { patients }\end{array}$ & \multicolumn{2}{c}{103 patients } & GRV $>100 \mathrm{~mL}$ \\
\hline $\mathrm{N}$ & $58(56.3 \%)$ & $45(43.7 \%)$ & \\
Age (years) & $61( \pm 11.0)$ & $61( \pm 12.7)$ & 0.99 \\
Male sex & $29(50 \%)$ & $21(46.7 \%)$ & 0.26 \\
BMI & $26.2 \pm 3.5$ & $26.7 \pm 4.02$ & 0.57 \\
\hline
\end{tabular}

GRV: gastric residual volume.

Elapsed time between the ending of mannitol ingestion and the examination was $123.1 \pm 49.7 \mathrm{~min}$. with GRV $\leq 100 \mathrm{~mL}$ and $95.3 \pm 36.4 \mathrm{~min}$. with GRV $>100 \mathrm{~mL}$. There was statistical significance regarding the usage of ezetimibe in the group with GRV $\leq 100 \mathrm{~mL}$. and the usage of paroxetine and tadalafil, surgical history containing prostatectomy and intestinal bridle surgical treatment for GRV $>100 \mathrm{~mL}$. The other variables analyzed are in the TABLES 2 and 3.
TABLE 2. Clinical data of the patients.

\begin{tabular}{|c|c|c|c|}
\hline & $\mathrm{GRV}>100 \mathrm{~mL}$ & $\mathrm{GRV} \leq 100 \mathrm{~mL}$ & $P$-value \\
\hline $\mathrm{N}$ & $58(56.3 \%)$ & $45(43.7 \%)$ & \\
\hline $\begin{array}{l}\text { Normal } \\
\text { colonoscopy }\end{array}$ & $23(40 \%)$ & $14(31.5 \%)$ & 0.62 \\
\hline Use of ezetimibe & $0(0 \%)$ & $6(13.7 \%)$ & 0.03 \\
\hline $\begin{array}{l}\text { Use of } \\
\text { paroxetine }\end{array}$ & $3(6.7 \%)$ & $0(0 \%)$ & 0.02 \\
\hline Use of tadalafil & $3(6.7 \%)$ & $0(0 \%)$ & 0.02 \\
\hline $\begin{array}{l}\text { Bridle } \\
\text { withdrawal }\end{array}$ & $3(6.7 \%)$ & $0(0 \%)$ & 0.02 \\
\hline Prostatectomy & $3(6.7 \%)$ & $0(0 \%)$ & 0.02 \\
\hline Obstipation & $11(20 \%)$ & $5(9.6 \%)$ & 0.19 \\
\hline $\begin{array}{l}\text { N. evacuations/ } \\
\text { week }\end{array}$ & $6.3 \pm 2.2$ & $5.8 \pm 1.9$ & 0.22 \\
\hline $\begin{array}{l}\text { N. evacuations } \\
\text { after bisacodil }\end{array}$ & $4 \pm 2.3$ & $4.3 \pm 3.1$ & 0.67 \\
\hline $\begin{array}{l}\text { N. evacuations } \\
\text { after manitol }\end{array}$ & $6.4 \pm 1.4$ & $6.5 \pm 2.0$ & 0.81 \\
\hline
\end{tabular}

Type $3=6(10 \%) \quad$ Tipo $3=3(6.8 \%)$

Fecal type $\quad$ Type $4=15(23.3 \%) \quad$ Tipo $4=9(19.2 \%)$

Type $5=25(43.3 \%) \quad$ Tipo $5=26(56.2 \%)$

0.82

Type $6=6(10 \%) \quad$ Tipo $6=5(9.6 \%)$

Type $7=2(3.3 \%) \quad$ Tipo $7=1(2.7 \%)$

\begin{tabular}{|c|c|c|c|}
\hline \multirow{3}{*}{ Diet type } & $C=33(56.7 \%)$ & $C=24(53.4 \%)$ & \multirow{3}{*}{0.95} \\
\hline & $\mathrm{F}=17(30 \%)$ & $\mathrm{F}=14(31.5 \%)$ & \\
\hline & $\mathrm{P}=8(13.3 \%)$ & $\mathrm{P}=7(15.1 \%)$ & \\
\hline
\end{tabular}

C: carbohydrates; F: fibers; P: proteins

TABLE 3. Evaluated factors after starting mannitol ingestion.

\begin{tabular}{|c|c|c|c|}
\hline & $\mathrm{GRV}>100 \mathrm{~mL}$ & $\mathrm{GRV} \leq 100 \mathrm{~mL}$ & $P$-value \\
\hline $\mathrm{N}$ & $58(56.3 \%)$ & $45(43.7 \%)$ & \\
\hline $\begin{array}{l}\text { Mannitol ingestion } \\
\text { time period (minutes) }\end{array}$ & $47.2(\mathrm{SD}=13.5)$ & $44.3(\mathrm{SD}=18.2)$ & 0.429 \\
\hline $\begin{array}{l}\text { Mannitol starting } \\
\text { time and the third } \\
\text { evacuation (minutes) }\end{array}$ & $47.8(\mathrm{SD}=28.7)$ & $52(\mathrm{SD}=28.2)$ & 0.498 \\
\hline $\begin{array}{l}\text { Total number of } \\
\text { evacuations at home }\end{array}$ & $4(\mathrm{SD}=2.3)$ & $4.3(\mathrm{SD}=3.1)$ & 0.676 \\
\hline $\begin{array}{l}\text { Total number of } \\
\text { evacuations in the } \\
\text { institution }\end{array}$ & $6.4(\mathrm{SD}=1.4)$ & $6.5(\mathrm{SD}=2.0)$ & 0.816 \\
\hline $\begin{array}{l}\text { End of mannitol } \\
\text { ingestion and } \\
\text { colonoscopy start } \\
\text { (minutes) }\end{array}$ & $95.3(\mathrm{SD}=36.4)$ & $\begin{array}{c}123.1 \\
(\mathrm{SD}=49.7)\end{array}$ & 0.003 \\
\hline
\end{tabular}

Colonoscopy findings per patients were: colon polyp on 41 $(39.8 \%)$ patients, colon diverticulum on $26(25.2 \%)$, rectal polyp on $5(4.9 \%)$, colon erosion on $5(4.9 \%)$, lateral spreading tumor $3(2.9 \%)$, colon hyperemia on $2(1.9 \%)$, angiectasias on $2(1.9 \%)$, colorectal anastomosis on $2(1.9 \%)$, erosive colitis on $2(1.9 \%)$, scarring in the rectum on $2(1.9 \%)$, colon lipoma on $2(1.9 \%)$ and rectitis on $2(1.9 \%)$. 


\section{DISCUSSION}

The American Society of Anesthesiologists recommends a 2-hour fasting of liquids, except for alcohol, before starting the sedation, based on the meta-analysis of randomized clinical trials that show a low risk of aspiration when liquids are given to patients in a time period between 2 and 4 hours before the anesthetic procedure (category A1 - evidence B) ${ }^{(1)}$. Data with human beings shows volumes below $1.5 \mathrm{~mL} / \mathrm{kg}$ in adults are normal in the fasting, not being related to clinical significant aspiration ${ }^{(4-8)}$.

By nature, liquids for the bowel preparation are light and protocols do not specify how they should react on the patient who is being prepared for colonoscopy examination. Despite that, plenty of anesthesiologists and medical centers request a fasting of 3 to 8 hours before the sedation.

Based on the Roberts and Shirley 1974 experiment $^{(9)}$, in which the injection of acid solution ( $\mathrm{pH}=2.5)$ directly into lungs of apes would result in adverse effects, it was assumed that the bronquic aspiration of $25 \mathrm{~mL}$ of gastric solution could have the same effects on human beings ${ }^{(10-14)}$. However, patients who submit themselves to elective surgery usually have a gastric fluid volume above $25 \mathrm{~mL}$, even with an overnight fasting ${ }^{(2)}$, once there is still production of saliva and gastric juice by approximately $50 \mathrm{~mL} / \mathrm{h}^{(10)}$. This is corroborated by studies that demonstrate that patients who ingest fluids 2 to 4 hours before the surgery do not have a residual gastric volume bigger than the patients who had a longer time period of fasting $(25 \mathrm{~mL})$ and patients without pre-anesthetic medication ${ }^{(10,11)}$. Additionally, adverse events only happen with the aspiration of volumes above $25 \mathrm{~mL}^{(9,10,14-22)}$ and patients, while fasting, produce saliva in an amount of nearly $50 \mathrm{~mL} / \mathrm{h}$, which will be swallowed and, consequentially, be part of the gastric liquid volume ${ }^{(10)}$.

It was believed that, in the bronquic aspiration, the gastric liquid $\mathrm{pH}$ and the amount of volume aspirated would be key factors for the occurrence of chemical bronchopneumonia, and that a prolonged fasting of liquid content would decrease the gastric residual volume. However, studies published up until 20 years ago have shown that the gastric volume and $\mathrm{pH}$ do not show significant changes after 2 hours of fasting.

Scarr et al. ${ }^{(10)}$ evaluated 211 patients divided in less than 3 hours, 3 to 4.9 hours, 5 to 8 hours and more than 8 hours of fasting, all of which were submitted to general anesthesia and concluded that there was no significant statistical difference of GRV and gastric $\mathrm{pH}$ between the groups.

Juvin et al. ${ }^{(20)}$ compared the $\mathrm{pH}$ and GRV of 25 obese patients with 23 thin patients and concluded there was no difference of the GRV ( $26 \pm 13 \mathrm{~mL}$ vs $26 \pm 8 \mathrm{~mL})$. However, gastric $\mathrm{pH}$ in obese patients was slightly lower ( $\mathrm{pH} 2.3$ vs $\mathrm{pH} 2.8$ ).

Schimidt et al. ${ }^{(12)}$, comparing GRV and $\mathrm{pH}$ with 1 and 2 hours of fasting after ingesting $5 \mathrm{~mL} / \mathrm{kg}(\max .150 \mathrm{~mL})$ of clear liquid in the pre-general anesthesia period of 131 children between 1 and 16 years old, ASA 1 and 11 without gastrointestinal disorders, concluded that, despite significantly shorter fasting times for clear fluids in group A compared with group B (76/136 min; $P<0.001)$, no significant difference was observed regarding gastric $\mathrm{pH} 1.43$ (1.30-1.56) vs $1.44(1.29-1.68), P=0.66$ or residual volume 0.43 $(0.21-0.84)$ vs $0.46(0.19-0.78) \mathrm{mL} / \mathrm{kg}, P=0.47$. Perhaps this applies only to children because in our series there was a significant difference in adults ( $95.3 \times 123.1$ minutes; $P=0.003)$.

Huffman et al. ${ }^{(13)}$ divided 712 patients into two groups: one group submitted to isolated upper endoscopy $(n=411)$ and one group submitted to colonoscopy associated with upper endoscopy, divided in two groups: to one group $(n=47)$, bowel preparation was done with $4 \mathrm{~L}$ of Polyethylene glycol or sodium picosulfateat at the morning of the exam and to another group, part of $(n=254)$ of the bowel preparation at home and the other part at the morning of the examination. The group with upper endoscopy only was oriented to total fasting over the night before the colonoscopy examination. Comparing all groups, GRV was bigger in the groups in which the colonoscopy was performed $(P=0.0001)$ with no difference between both groups with bowel preparation $(P=0.85)$. Volumes above $50 \mathrm{~mL}$ were found in $8 \%$ of the patients that started the bowel preparation at home, in $9 \%$ of the patients with whole bowel preparation at the morning of the exam and in 5\% whose upper endoscopy only was performed, with no identified factor associated to the raise of gastric volume. Diabetes, use of opioids, use of metoclopramine or the sort of preparation didn't show significance in the GRV when the liquid was aspirated 2 hours after the ingestion of the solution for the bowel preparation, the same results we found. Author didn't identify clinical factors related to the increase of gastric liquid retention, despite having patients with volumes above $100 \mathrm{~mL}$. In our study were found statistical significance to prostatectomy $(P=0.02)$ and intestinal bridle surgical treatment $(P=0.02)$ for GRV $>100 \mathrm{~mL}$.

In 161 patients in use of Percutaneous Endoscopic Gastrostomy, Agrawal D. et al. ${ }^{(14)}$ found an average GRV of $21 \mathrm{~mL} \pm 254$ $\mathrm{mL}$ for the ingestion of 4 liters by PEG at the morning of the exam, with no difference for a fasting of 2, 2,5 and 3 hours (average of $27 \pm 29,16 \pm 26$ and $17 \pm 14$, accordingly; $P=0.27$ ), as well as the coexistence of diabetes, gastroparesis and use of opioids. Five patients presented a volume above $100 \mathrm{~mL}$, without any adverse effects.

Coriat et al. ${ }^{(23)}$, with ingestion of 4 tablets of sodium phosphate diluted in $250 \mathrm{~mL}$ of liquid every 15 minutes (total of 16 tablets and $1000 \mathrm{~mL}$ ) in the morning of the examination, controlled by ultrasound evaluation, observed gastric emptying of $25 \%$ after 60 minutes of the ingestion, $70 \%$ by 120 minutes and $87 \%$ by 150 minutes with no significance for the emptying when considering the body mass index (BMI). Despite results previously described, we observed patients with GRV $>100 \mathrm{~mL}$ had a shorter average fasting time than those who had GRV $\leq 100 \mathrm{~mL}(95.3 \times 123.1 \mathrm{~min}$; $P=0.003$ )

Paroxetine inhibits the recapture of 5-hydroxytryptamine (5HT). On rabbits, it causes a dose-dependent decrease on the ileum contractility $^{(15)}$ and on human beings may promote a delay on the gastric emptying, despite accelerating the orocecal transit ${ }^{(16,18,22)}$. Maybe this effect can explain the result found in our study. Comparing the effects on the gastrointestinal tract by buspirone, paroxetine and venlafaxine, Chial et al. ${ }^{(19)}$ concluded there was no significant difference $(P=0.3)$ on the gastric emptying time $(\mathrm{t}=2 \mathrm{~h})$ for solid content. Paroxetine, when compared to placebo, accelerated the orocecal transit time to 6 hours 82 (41.3 to 99$) \%$ vs $47(24.5 \%$ to $59) \%, P=0.05)$, without alterating the colon transit. Besides that, it did not have effect on the postprandial gastric volume.

Despite not being any directed studies about the effects of tadalafil and ezetimibe, surgery for the withdrawal of bridles and usage of mannitol over the gastric residual volume, Remes-Troche et al. ${ }^{(21)}$ describes effect of tadalafil on the treatment of spastic esophageal disorder due to its muscle relaxation effect over the esophagus' smooth muscle. After de injection of $20 \mathrm{mg}$ of tadalafil on a control group, on four patients with achalasia and on two patients with hypertensive peristalsis, by manometric evaluation of 15,30 , 
45, 60 and 120 minutes, 24 and 48 hours, was noticed a progressive resting pressure decrease of the inferior esophageal sphincter after 60 minutes in the control group $(18.8 \pm 4 \mathrm{mmHg}$ vs $22.1 \pm 3 \mathrm{mmHg}$, $P=0.019$ ), reaching the lowest point after 2, 24 and 48 hours. Out of the six patients with peristalsis condition, four of them noticed an improvement on their dysphagia between 24 and 48 hours. In tadalafil's medicine leaflet, side effects may include abdominal pain and gastric-esophageal reflux. As for the ezetimibe, the medicine leaflet describes abdominal pain, diarrhea and flatulence as possible side effects. For us, tadalafil is related to GRV $>100 \mathrm{~mL}(P=0.02)$ and the use of ezetimibe is related to decreased GRV $\leq 100 \mathrm{~mL}(P=0.03)$.

Studies ${ }^{(2,24,25)}$ point out liraglutide in patients with diabetes mellitus type II as the prompter of gastric emptying delay and inhibitor of duodenal and small intestine motility. We observed patients using this medication did not show statistical significance ( $P=0.146$ ) on the GRV when suspending it seven days before having a colonoscopy examination.

This is the first study with mannitol bowel preparation that tries to define factors related to the time of gastric emptying and can contribute to daily endocopic practice, providing scientific subsidies for those services that have already adopted fasting time reduction, being able to assist the examination scheduling logistics and the individualized orientation for patient. Besides that, it may also provide data for future studies that evaluate factors that can interfere on it.

\section{CONCLUSION}

We may conclude the usage of ezetimibe and fasting above 2 hours after the ingestion of mannitol decrease significantly the incidence of a GRV $>100 \mathrm{~mL}$. The usage of paroxetine, tadalafil and surgical history of prostatectomy or bridle withdrawal may contribute to increase de incidence of a GRV $>100 \mathrm{~mL}$.

\section{Authors' contribution}

Brito HP: data acquisition, analysis, data interpretation, article writing, article review. Chaves DM: data acquisition, data interpretation, article review, final approval. Chaves FT: data acquisition, translation, article writing. Sugai B: data acquisition, article writing, article review. Ide E: data acquisition, article writing, article review. Rodrigues RA: data acquisition, article writing, article review.

\section{Orcid}

Hélcio Pedrosa Brito: 0000-0003-4170-2247.

Beatriz Sugai: 0000-0001-6817-4152.

Filipe Tomishige Chaves: 0000-0002-7177-2724.

Edson Ide: 0000-0003-4533-6117.

Rodrigo Rodrigues: 0000-0002-0922-839X.

Dalton Marques Chaves: 0000-0003-4026-533X.

Brito HP, Sugai B, Chaves FT, Ide E, Rodrigues RA, Chaves DM. Fatores predisponentes do volume residual gástrico após preparo expresso com manitol. Arq Gastroenterol. 2021;58(2):180-4.

RESUMO - Contexto - O preparo intestinal com manitol é um método bem estabelecido no Brasil. No entanto, os fatores que interferem no tempo de esvaziamento gástrico ainda não são conhecidos. O conhecimento desses fatores pode favorecer a logística de agendamento do exame e a orientação individualizada para cada paciente. Objetivo - Estudar os fatores que podem contribuir para o tempo de esvaziamento gástrico após o preparo intestinal com manitol expresso. Métodos - Trata-se de um estudo observacional prospectivo com o objetivo de conhecer os seguintes fatores que podem contribuir no tempo de esvaziamento gástrico: tipo de dieta predominante, comorbidades, uso de medicamentos, cirurgias anteriores, número de evacuações por semana, portador de obstipação intestinal, tipo fecal, tipo de dieta, número de evacuações após o uso domiciliar de bisacodil antes da ingestão de manitol e número de evacuações após a ingestão de manitol até atingir o preparo intestinal adequado. Antes de iniciar o preparo intestinal, os pacientes responderam a um questionário clínico. O endoscópio foi introduzido para aspirar o conteúdo gástrico, antes de iniciar a colonoscopia. Resultados - A amostra foi composta por 103 pacientes, sendo 55 mulheres, com média de idade de 61 anos, peso médio de 75,3 kg, altura média de $1,7 \mathrm{~m}$ e IMC médio de $26,6 \mathrm{~kg} / \mathrm{m}^{2}$. O volume residual gástrico médio medido foi 120,9 (0-900) mL. Volume residual gástrico inferior a $100 \mathrm{~mL}$ (VRG $\leq 100 \mathrm{~mL}$ ) foi encontrado em $45(43,6 \%)$ pacientes, sendo $24(53,3 \%)$ mulheres, com média de idade de 61,0 anos e IMC médio de $26,7 \mathrm{~kg} / \mathrm{m}^{2}$. Volume residual gástrico acima de $100 \mathrm{~mL}$ (VRG >100 mL) ocorreu em $58(56,3 \%)$ pacientes, sendo $29(50 \%)$ mulheres, com idade média de 61,0 anos e IMC médio de $26,2 \mathrm{~kg} / \mathrm{m}^{2}$. Comparando os dois grupos, notou-se que o tempo médio de jejum após a ingestão de manitol foi significativamente maior no grupo com VRG $\leq 100 \mathrm{~mL}$ do que no grupo com VRG> $100 \mathrm{~mL}, 123,1$ (60-246) vs 95,3 (55-195) minutos, respectivamente. Também houve significância estatística em relação ao uso de ezetimiba $6(13,7 \%)$, sendo maior no grupo com VRG $\leq 100 \mathrm{~mL}$. Além disso, houve significância estatística no grupo com VRG $>100 \mathrm{~mL}$ quanto ao uso de paroxetina $3(6,7 \%)$ e tadalafil $3(6,7 \%)$ e história cirúrgica de prostatectomia $3(6,7 \%)$ e retirada de bridas $3(6,7 \%)$. Conclusão - Podemos concluir neste estudo que o uso de ezetimiba e o jejum acima de 2 horas após a ingestão de manitol diminuem significativamente a incidência de um VRG $>100 \mathrm{~mL}$. O uso de paroxetina, tadalafil e história cirúrgica de prostatectomia ou retirada de bridas podem contribuir para o aumento da incidência de um VRG $>100 \mathrm{~mL}$.

Palavras-chave - Manitol; sedação; aspiração respiratória do conteúdo gástrico; sedação consciente. 


\section{REFERENCES}

1. Practice Guidelines for Preoperative Fasting and the Use of Pharmacologic Agents to Reduce the Risk of Pulmonary Aspiration: Application to Healthy Patients Undergoing Elective Procedures: An Updated Report by the American Society of Anesthesiologists Task Force on Preoperative Fasting and the Use of Pharmacologic Agents to Reduce the Risk of Pulmonary Aspiration. Anesthesiology. 2017;126:376-93.

2. Lacy BE, Mearin F, Chang L, Chey WD, Lembo AJ, Simren M, et al. Bowe Disorders. Gastroenterology. 2016;S0016-5085:00222-5. doi: 10.1053/j.gastro.2016.02.031

3. Perlas A, Arzola C, Van de Putte P. Point-of-care gastric ultrasound and aspiration risk assessment: a narrative review. Can J Anaesth. 2018;65:437-48.

4. Read MS, Vaughan RS. Allowing pre-operative patients to drink: effects on patients' safety and comfort of unlimited oral water until 2 hours before anaesthesia. Acta Anaesthesiol Scand. 1991;35:591-5.

5. Phillips S, Hutchinson S, Davidson T. Preoperative drinking does not affect gastric contents. Br J Anaesth. 1993;70:6-9.

6. Harter RL, Kelly WB, Kramer MG, Perez CE, Dzwonczyk RR. A comparison of the volume and $\mathrm{pH}$ of gastric contents of obese and lean surgical patients Anesth Analg. 1998;86:147-52.

7. Hausel J, Nygren J, Lagerkranser M, Hellström PM, Hammarqvist F, Almström $\mathrm{C}$, et al. A carbohydrate-rich drink reduces preoperative discomfort in elective surgery patients. Anesth Analg. 2001;93:1344-50.

8. Lobo DN, Hendry PO, Rodrigues G, Marciani L, Totman JJ, Wright JW, et al. Gastric emptying of three liquid oral preoperative metabolic preconditioning regimens measured by magnetic resonance imaging in healthy adult volunteers: a randomised double-blind, crossover study. Clin Nutr. 2009;28:636-41.

9. Roberts RB, Shirley MA. Reducing the risk of acid aspiration during cesarean section. Anesth Analg. 1974;53:859-68.

10. Scarr M, Maltby JR, Jani K, Sutherland LR. Volume and acidity of residual gastric fluid after oral fluid ingestion before elective ambulatory surgery. CMAJ. 1989;141:1151-4.

11. Hutchinson A, Maltby JR, Reid CRG. Gastric fluid volume and $\mathrm{pH}$ in elective inpatients. Part I: coffee or orange juice versus overnight fast. Can J Anaesth. 1988:35:12-5.

12. Schmidt AR, Buehler P, Seglias L, Stark T, Brotschi B, Renner T, et al. Gastric $\mathrm{pH}$ and residual volume after 1 and $2 \mathrm{~h}$ fasting time for clear fluids in children. Br J Anaesth. 2015;114:477-82.
13. Huffman M, Unger RZ, Thatikonda C, Amstutz S, Rex DK. Split-dose bowe preparation for colonoscopy and residual gastric fluid volume: an observational study. Gastrointest Endosc. 2010;72:516-22

14. Agrawal D, Elsbernd B, Singal AG, Rockey D. Gastric residual volume after split-dose compared with evening-before polyethylene glycol bowel preparation. Gastrointestinal Endoscopy. 2016;83:574-80.

15. Spiller R. Serotonergic modulating drugs for functional gastrointestinal diseases Br J Clin Pharmacol. 2002;5:11-20

16. Misiewicz JJ, Waller SL, Eisner M. Motor responses of human gastrointestina tract to 5-hydroxytryptamine in vivo and in vitro. Gut. 1966;7:208-16.

17. Gershon MD, Wade PR, Kirchgessner AL, Tamir H. 5-HT receptor subtypes outside the central nervous system. Roles in the physiology of the gut. Neuropsychopharmacology. 1990;3:385-95.

18. Gorard DA, Libby GW, Farthing MJ. Influence of antidepressants on whole gut and orocaecal transit times in health and irritable bowel syndrome. Aliment Pharmacol Ther. 1994;8:159-66.

19. Selective effects of serotonergic psychoactive agents on gastrointestinal functions in health | American Journal of Physiology-Gastrointestinal and Liver Physiology [Internet]. [cited 2020 Aug 24]. Available from: https://journals.physiology.org/ doi/full/10.1152/ajpgi.00266.2002

20. Juvin P, Fèvre G, Merouche M, Vallot T, Desmonts J-M. Gastric Residue is Not More Copious in Obese Patients: Anesth Analg. 2001;93:1621-2.

21. Remes-Troche JM. Trastornos funcionales esofágicos. Revista de Gastroenterología de México. 2013;78:28-30. DOI: 10.1016/j.rgmx.2013.06.011

22. Akkermans LM, Vos A, Hoekstra A, Roelofs JM, Horowitz M. Effect of ICS 205-930 (a specific 5-HT3 receptor antagonist) on gastric emptying of a solid meal in normal subjects. Gut. 1988;29:1249-52.

23. Coriat R, Polin V, Oudjit A, Henri F, Dhooge M, Leblanc S, et al. Gastric emptying evaluation by ultrasound prior colonoscopy: an easy tool following bowe preparation. World J Gastroenterol. 2014;20:13591-8.

24. Nakatani Y, Maeda M, Matsumura M, Shimizu R, Banba N, Aso Y, et al. Effect of GLP-1 receptor agonist on gastrointestinal tract motility and residue rates as evaluated by capsule endoscopy. Diabetes Metab. 2017;43:430-7.

25. van Can J, Sloth B, Jensen CB, Flint A, Blaak EE, Saris WHM. Effects of the once-daily GLP-1 analog liraglutide on gastric emptying, glycemic parameters, appetite and energy metabolism in obese, non-diabetic adults. Int J Obes (Lond). 2014:38:784-93. 